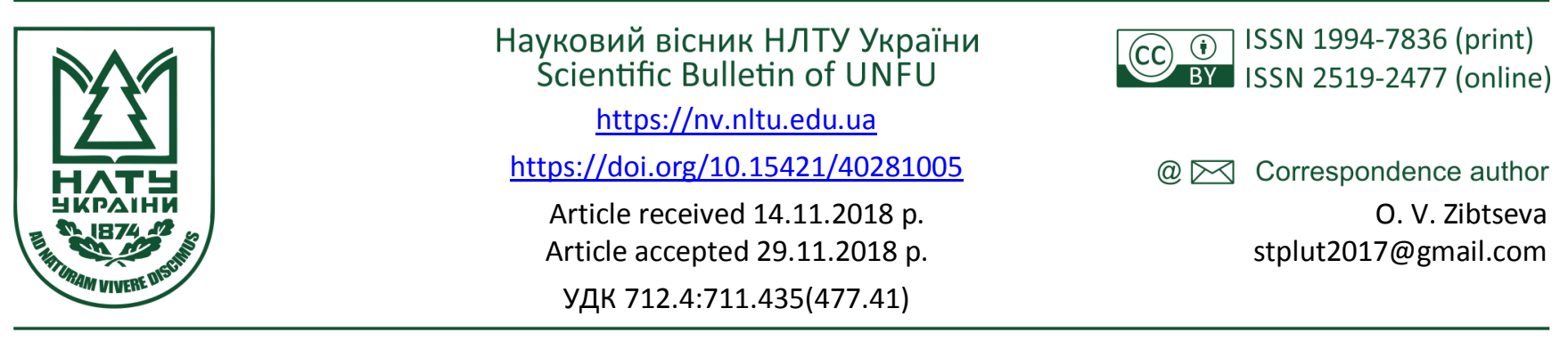

О. В. Зібцева

Національний університет біоресурсів і природокористування Украӥни, м. Київ, Україна

\title{
ОЗЕЛЕНЕННЯ ЗАБУДОВАНИХ ТЕРИТОРІЙ МАЛИХ МІСТ У КОНТЕКСТІ ДОТРИМАННЯ ДЕРЖАВНИХ БУДІВЕЛЬНИХ НОРМ
}

\begin{abstract}
Стале міське землекористування передбачає дотримання чинних національних стандартів. Відстежено дотримання вимог державних будівельних норм (ДБН 360-92. Планування і забудова міських і сільських поселень) щодо планування міст у частині формування системи зелених насаджень на прикладі території малого історичного міста Вишгород Київської області. Виявлено слабкі місця у нормативному документі та рекомендовано заходи з озеленення забудованих територій $з$ метою подальшої оптимізації містобудівного планування в Україні. Дослідження виконано у чіткій послідовності відповідно до вимог, викладених у ДБН-360-92 з порівнянням реальної ситуації на території міста, визначеної способом натурних обстежень. Методи дослідження - експертно-аналітичні. Встановлено, що на території дослідного міста зазначені нормативні рекомендації порушують або взагалі ігнорують. Не дотримано мінімальні відстані насаджень дерев і кущів від будівель $\mathrm{i}$ споруд, вуличні насадження мають обмежений асортимент кущових рослин. Ущільнене будівництво зазвичай здійснюють за рахунок територій зелених насаджень, зокрема центрального парку міста. Не дотримано рекомендації щодо максимального збереження ділянок із існуючими насадженнями. Нормативи з влаштування майданчиків різного функціонального призначення на прибудинкових територіях житлових масивів давно забуто, що, можливо, потребує перегляду самих нормативів, викладених у ДБН.
\end{abstract}

Ключові слова: зелені насадження; парк; планування; сталий розвиток.

Вступ. Відродження незалежності України принципово змінило пріоритети в плануванні просторового розвитку держави і створило необхідні передумови для розробки національної стратегії планування (Bilokon, 2009). Найоптимальнішим принципом управління просторовим розвитком території є ієрархічний підхід, який передбачає послідовну розробку містобудівної документації на загальнодержавному, регіональному та місцевому рівнях (Kireieva et al., 2013). Нормування зеленого простору дає змогу вирішити проблеми міського життя (Fuller \& Gaston, 2009). Актуальним є перегляд i вдосконалення методології містобудівного планування в умовах децентралізації інвестиційної діяльності, змін у землекористуванні, характері містобудівного процесу й необхідності посилення ролі екологічної складової у містобудуванні України (Yehorov, 2008).

Аналіз останніх досліджень та публікацій. Важливим механізмом територіального планування землекористування є створення узгодженої системи національних стандартів, норм та правил для забезпечення сталого землекористування (Dorosh \& Dorosh, 2017). Державні будівельні норми (ДБН) є засобом технічного регулювання стандартизації у сфері територіального планування землекористування, що передбачає не лише встановлення екологічних нормативів у нормативно-технічних документах, але й технічне регулювання режимів землекористування і природоохоронних заходів завдя- ки встановленню рекомендаційних норм. Водночас існуюча система нормативів характеризується безсистемністю, розпорошеністю та фрагментарністю. Тому актуальним є завдання визначення та упорядкування об'єктів нормування і стандартизації, основних понять і термінів. Мінрегіонбуд анонсує істотне посилення містобудівного законодавства (Bardakov, 2018). Експерти вважають, що за останні 20 років грубо порушуються 109 державних будівельних норм, 27 з яких - основоположні для галузі. Натомість більшість запропонованих норм уже присутні в законодавстві, а нововведення скопійовані з російської нормативної бази або переведені 3 європейських дилетантами, які їх перекрутили та допустилися низки грубих помилок.

Основоположною частиною сталого міського розвитку $є$ багатофункціональний зелений простір, який конкурує з іншими видами землекористування і часто сприймається як земельний резерв для житлового будівництва. Ущільнення міських поселень як принцип сталого зростання призводить до його втрати, внаслідок чого навіть у малих містах Західної Свропи спостерігається низька забезпеченість зеленим простором (Тарpert et al., 2018). Тому значно поширеним підходом у програмі сталого міського розвитку є практика озеленення міст. Планування міського зеленого простору є основою сталого розвитку, вирішальним щодо поліпшення екологічного середовища (Luo, 2014). Приємна,

\section{Інформація про автора:}

Зібцева Ольга Василівна, канд. с.-г. наук, доцент, кафедра ландшафтної архітектури та садово-паркового будівництва. Email: stplut2017@gmail.com

Цитування за ДСту: Зібцева О. В. Озеленення забудованих територій малих міст у контексті дотримання державних будівельних норм. Науковий вісник НЛтУ України. 2018, т. 28, № 10. С. 28-31.

Citation APA: Zibtseva, O. V. (2018). Greening of built-up areas of small towns in the context of compliance with state building norms. Scientific Bulletin of UNFU, 28(10), 28-31. https://doi.org/10.15421/40281005 
зручна система зеленого простору з унікальними звичаями та місцевою культурою особливо важлива для малих міст (Sun \& Miao, 2011). 3 посиленням сталого міського планування ідеал компактного зеленого міста ствердився у глобальному масштабі (Tappert et al., 2018). Однак, забезпечення міського зеленого простору в компактних містах є головною проблемою (Haaland \& van den Bosch, 2015). Пріоритети щодо розподілу земель на міських зелених територіях зневажаються або легко домовляються в країнах, які перебувають у перехідному періоді. Тому в містобудівне планування, незалежно від розміру міст, рекомендують включати індекс озеленення, а в планах - резервувати простір для зелених насаджень (Ivesab et al., 2017). На жаль, під час аналізу містобудівних та санітарно-гігієнічних аспектів планування території областей України, наприклад Дніпропетровської (Kireieva et al., 2013), про аспекти планування зелених насаджень навіть не згадують. Дослідження екологічного стану малих міст Львівської області показали, що благоустрою їх території за останні 50 років не надавали жодного значення і тут чітко окреслюють проблеми озеленення (Kharkhalis et al., 2004). Відповідно до генеральних планів малих міст, наразі пропонують занадто узагальнені рішення щодо нормативних показників і в багатьох випадках не можуть бути інструментом для виконання конкретних завдань (Petryshyn et al., 2013). У сучасних соціально-економічних умовах необхідне вдосконалення нормативно-правової бази, використовуваної для вирішення проблем озеленення міських територій, диференційований підхід до озеленення, введення мораторію на ліквідацію зелених площ у центральних районах міст, встановлення норм для нових районів, де озеленення практично немає (Panchuk, 2016).

Мета дослідження - відстежити дотримання на практиці вимог державних будівельних норм (ДБН-36092. Планування і забудова міських і сільських поселень) щодо планування зелених насаджень на прикладі території малого міста Вишгорода Київської області, виявити слабкі місця в нормативному документі з цього питання та надати рекомендації з удосконалення стандарту для подальшої оптимізації містобудівного планування в Україні в контексті сталого екозбалансованого розвитку.

Матеріали та методика дослідження. Зіставлення вимог ДБН-360-92 щодо озеленення населених пунктів iз фактичною ситуацією на території малого історичного міста Вишгорода Київської області проведено на підставі аналітичних досліджень Генерального плану міста, натурного обстеження міської території, яка не підпадає під історико-архітектурні обмеження (рисунок) та інвентаризації зелених насаджень (Zibtseva, 2014).

Методи дослідження - загальнонаукові (логічний, системний), експертно-аналітичні та порівняльні.

Результати дослідження та їх обговорення. Щільність багатоквартирної забудови в центральній частині міста свідчить про те, що забудовники не звертали увагу на відстань між житловими будинками, яку мала б приймати на підставі розрахунків інсоляції та освітленості відповідно норми і яка не може бути меншою за 6 м. Між довгими сторонами житлових будинків висотою понад чотири поверхи відстані становлять менше нормативних $20 \mathrm{м}$.

Не дотримані вимоги щодо площі озелененої території житлового кварталу, яка мала би бути не менше

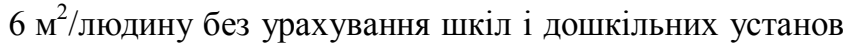
і містити майданчики для відпочинку, для ігор дітей. Взагалі, не звертають увагу на те, що житлова забудова має містити нормований перелік майданчиків певного призначення, розміру і відстані від вікон житлових будівель, а саме: для ігор дітей дошкільного і молодшого шкільного віку $(0,7$ м²/людину); для відпочинку дорослого населення $\left(0,1 \mathrm{~m}^{2} /\right.$ людину); для занять фізкульту-

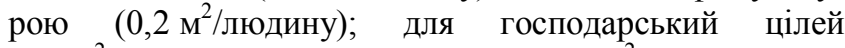
(0,3 м²/людину); для вигулу собак (0,3 м²/людину); для авто стоянки $\left(0,8 \mathrm{~m}^{2} /\right.$ людину). Із зазначеного переліку максимальна нормативна відстань - 40 м, передбачена для майданчика для вигулу собак і до 40 м для занять фізкультурою, насправді виявляється завеликою у сучасному ущільненому будівництві.

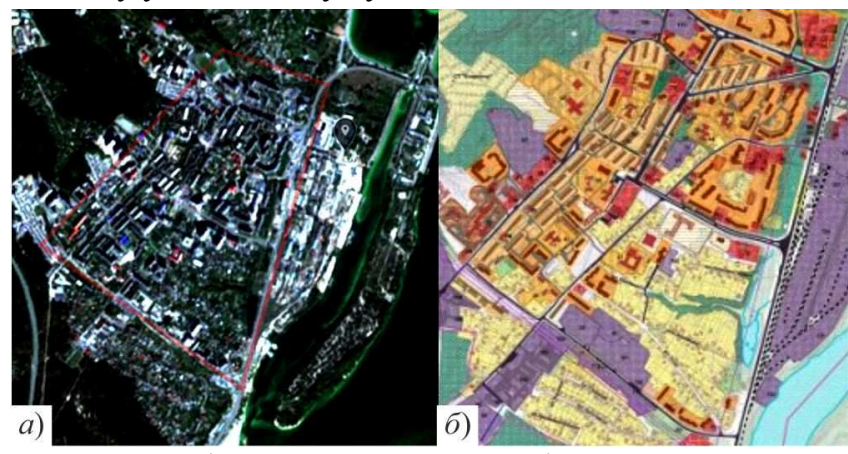

Рисунок. Досліджувана частина території м. Вишгорода

(Landsat, 2018 та фрагмент плану існуючого стану міста за матеріалами Генерального плану)

У садибній забудові м. Вишгорода, відповідно до рекомендацій ДБН, у насадженнях вздовж вулиць $є$ плодові дерева, але, всупереч рекомендаціям, немає кущів. Озеленення вулиць шириною менше 12 м, як і рекомендовано, здійснено за рахунок палісадників, але в такому разі в ДБН, на наш погляд, мали би бути прописані вимоги до огорож садиб, за якими ці палісадники розташовані. Відповідно до вимог ДБН, на території житлової забудови Вишгорода трапляються майданчики для ігор дітей біля будинків. Однак питому вагу озеленених територій різного призначення в межах забудови міста, яка має становити не менше $40 \%$, на дослідній території не дотримано.

Час доступності до міських парків дотримується зазвичай в усіх малих містах внаслідок їх порівняно невеликої і переважно компактної форми. На жаль, лише в 25 \% малих міст Київської області взагалі є парки. У ДБН зазначено лише, що площу території парків, садів і скверів варто приймати відповідно до конкретних містобудівних і природних умов. Допустима кількість одночасних відвідувачів парків 100 люд./га теоретично дає змогу бути присутніми в парку м. Вишгорода (площею 2 га) одночасно лише 200 людям або 0,7\% населення. За стандартами (в розрахунку на відвідування $10 \%$ населення), площа парків мала би становити близько 28 га.

ДБН передбачено наявність спеціалізованих, зокрема дитячих, парків (0,5 м²/людину) лише в більших, великих містах. Доцільно додати вимогу створення дитячих парків у малих містах, що швидко розростаються за рахунок багатоквартирної житлової забудови і мають стрімку позитивну демографічну динаміку, особливо в зоні впливу великих міст, таких як Київ.

У Вишгороді є території з високим ступенем збереженості природних ландшафтів, які мають естетичну і 
пізнавальну цінність, що передбачає вимоги формування національних і природних парків, які можна використовувати 3 рекреаційною метою, 3 виділенням рекреаційної зони. Розміщення парків і садів передбачає максимальне збереження ділянок із існуючими насадженнями, що в місті взагалі не дотримують (приклад знищений у центрі міста парк "Берізки" площею 9 га перетворено на багатоповерхову забудову).

Передбачено нормативи щодо площ озеленених територій парків, садів та інших об'єктів у їх загальному балансі. Так, рівень озеленення парків має бути в межах 65-80\%, дитячих парків - 40-55\%, скверів - 75-85\%. Без чіткої регламентації розмірів парків, на практиці виникають розбіжності в трактуванні. Так, у Вишгороді озеленений простір у центральній частині міста розміром близько 1 га називають дитячим парком, хоча за нормативами він не може бути парком: 1) має розмір менше 2 га, тому має називатися сквером; 2) має рівень озеленення менше $50 \%$, тому за нормативами не може бути сквером.

Не дотримуються нормативні відстані від дерев і кущів до будівель, споруд та об'єктів інженерного благоустрою. Повсюдно дерева, кущі та ліани ростуть впритул до стін багатоквартирної забудови. Наразі абсолютно ігнорують заборону розміщувати житлові та громадські будівлі в межах санітарно-захисних зон ЛЕП, а промислово-складська зона розташовується впритул до Дніпра.

Вимога щодо наявності розсадника деревних і кущових рослин площею не менше 80 га та квітково-оранжерейних господарств площею з розрахунку 0,4 м²/людину 3 урахуванням забезпечення садивним матеріалом груп міських і сільських поселень наразі є рекламаційною, залишеною $з$ радянських часів, на яку кошти 3 міських бюджетів переважно не виділяють. Наявна прогалина у Вишгороді заповнена приватним садовим центром, на який чинні нормативи на практиці не поширюються.

Виокремлення в ДБН 360-92 окремого розділу "Зона відпочинку", яку варто передбачати на ландшафтнорекреаційних територіях міста (міська) та приміських зон (заміська), спричинює зайві непорозуміння у структурі ДБН, начебто перед цим насадження загального користування до зони відпочинку не належали. У ДБН зазначено, що зони короткочасного відпочинку потрібно розміщувати з урахуванням їх доступності на громадському транспорті не більше 1,5 год. Для малого міста це не $\epsilon$ актуальним. На жаль, відстань до зони тривалого відпочинку взагалі не нормується, лише зазначається, що іiі варто розміщувати за межами населених пунктів у найбільш сприятливих умовах, що не дає чітких уявлень щодо вимог до ії розташування.

Зазначений у ДБН нормативний розмір зони короткочасного відпочинку також не чіткий - 500$1000 \mathrm{~m}^{2} /$ відвідувача із зазначенням у тому числі нормативів площ для активного відпочинку, пляжів та площ на придатних для сільськогосподарського використання землях (не дуже зручне містобудівне проектування). При цьому нормується протяжність узбережної смуги пляжів, площа припляжної зони й екваторіальної. 3 огляду на поширену практику роздавання узбережних земель у приватну власність, дотримання перелічених вимог є мало реальним. Досить умовно викладено в ДБН нормоване рекреаційне навантаження на ландшафт зон короткочасного відпочинку (від 0,7 до 26,0 люд./га).
Окремий розділ ДБН рекомендує зберігати і раціонально використовувати природні ресурси під час планування і забудови, виділяти ландшафтно-рекреаційні території із забороною на них будівництва, дотримуватися санітарних норм. На жаль, допускається можливість забудови лісових, рекреаційних земель, заказників, курортів та земель під багаторічними насадженнями за рішенням Верховної Ради, що створює корупційний прецедент. Зазначено, що ліси зелених зон міст мають бути використовувані 3 рекреаційною, санітарно-гігієнічною і оздоровчою метою, але не вказано жодних нормативів. Тому ця рекомендація виглядає як необов'язкове побажання. Розміщення забудови на землях Держлісфонду допускається на не покритих лісом ділянках або чагарниках і малоцінних насадженнях (останнє на практиці вирішують легко, що дає змогу забудовникам активно зловживати цією вимогою на місцях).

Територіальна організація зелених зон міст має передбачати розподіл на лісопаркову і лісогосподарську частину, виділення місць відпочинку населення і охоронних зон, що на практиці не виконують у випадку малих міст. Окрім цього, у ДБН не чітко прописано номенклатуру структурних елементів території комплексної зеленої зони міста. Здебільшого не розмежовано функціональну приналежність структурних елементів, яку подають разом: обмеженого використання і спеціального призначення, повторювані в різних складових так звані "інші території" різного функціонального призначення, на що вже було зазначено у (Yukhnovskyi \& Zibtseva, 2018).

Висновки і перспективи. Встановлено, що на території дослідного малого міста зазначені нормативні рекомендації, викладені у ДБН 360-92, порушують або взагалі ігнорують. Так, не дотримують мінімальні відстані насаджень дерев і кущів від будівель і споруд, вуличні насадження бідні на кущові рослини. Ущільнене будівництво переважно здійснюється за рахунок територій зелених насаджень зокрема парку в центрі міста. Взагалі не дотримують рекомендації щодо максимального збереження ділянок із існуючими насадженнями. Нормативи щодо влаштування майданчиків різного функціонального призначення на прибудинкових територіях житлових масивів давно забуто, що, можливо, потребує перегляду й осучаснення самих нормативів, викладених у ДБН 360-92. Вважаємо доцільним введення прямого нормування мінімальної забезпеченості мешканців міст зеленими насадженнями всіх категорій, як це практикується у розвинених країнах, а також введення нормативів щодо площ енергетичних плантацій, що сприятиме сталості малих міст.

\section{Перелік використаних джерел}

Bardakov, O. (2018). Illusion of struggle: why the new restrictions on the development of territories cannot be put right on the market, April 20. Retrieved from: https://mind.ua/publications/20184120ilyuziya-borotbi-chomu-novi-obmezhennya-zabudovi-teritorij-nezmozhut-navesti-lad-na-rinku. [In Ukrainian].

Bilokon, Yu. M. (2009). Territorial planning in Ukraine: European principles and national experience. Dosvid ta perspektyvy rozvytku mist Ukrainy, 16, 9-23. Sotsialno-ekonomichni problemy mistobuduvannia. Kyiv: Dipromisto. [In Ukrainian].

Dorosh, Y. M., \& Dorosh, O. S. (2017). State standards, norms and rules as a mechanism of formation of the institutional environment of territorial planning of land use. Zemleustrii, kadastr i monitorynh zemel, 23. http//journals.nubip.edu.ua/index.php/Zemleustriy/article/view/6669/6525. [In Ukrainian]. 
Fuller, R. A., \& Gaston, K. J. (2009). The scaling of green space coverage in European cities. Biology Letters, 5(3), 352-355. https://doi.org/10.1098/rsbl.2009.0010

Haaland, C., \& van den Bosch, C. K. (2015). Challenges and strategies for urban green-space planning in cities undergoing densification: A review. Urban Forestry \& Urban Greening, 14, 760-771. https://doi.org/10.1016/j.ufug.2015.07.009

Ivesab, C. D., Okeac, C, Hehird, A., Gordona, A., Wangd, Y., \& Bekessya, S. A. (2017). Capturing residents values for urban green space: Mapping, analysis and guidance for practice. Landscape and Urban Planning, 161, 32-43. https://doi.org/10.1016/j.landurbplan.2016.12.010

Kharkhalis, B. I., Kharkhalis, M. B., Hozhelnyk, M. P., \& Yanchuk, O. V. (2004). Research of the ecological state of the Lviv region littlest towns. Scientific Bulletin of UNFU, 14(4), 275-283. [In Ukrainian].

Kireieva, I. S., Makhniuk, V. M., Lopotiuk, M. O., \& Mukha, V. H. (2013). Town-planning and sanitary and hygienic aspects of the Dnipropetrovsk region territort planning. Hihiiena naselenykh mists, 61, 22-34. [In Ukrainian].

Luo, M. (2014). Strategies for urban green space system plan based on the eco-oriented development mode BioTechnology. An Indian Journal, 10(19), 11446-11451.

Panchuk, A. A. (2016). Improvement of the organizational and economic mechanism of development of garden-park economy of urban agglomeration in current socio-economic conditions. Fundamental Research, 10(1), 171-177. [In Russian].
Petryshyn, H. P., Posatskyi, B. S., Kryvoruchko, Yu. I., \& Tupis, S. P. (2013). Problems of urban development of the central part of Khust town. Bulletin of the National University "Lviv Polytechnic". Series: Architecture, 757, 213-219. [In Ukrainian].

Sun, K., \& Miao, Z. (2011). Notions of green space system planning in medium and small city. International Conference on Remote Sensing, Environment and Transportation Engineering, June 24 26, Nanjing, China. https://doi.org/10.1109/RSETE.2011.5965462

Tappert, S., Klöti, T., \& Drilling, M. (2018). Contested urban green spaces in the compact city: The (re-) negotiation of urban gardening in Swiss cities. Landscape and Urban Planning, 170, 69-78. https://doi.org/10.1016/j.landurbplan.2017.08.016

Yehorov, Yu. I. (2008). Pryntsypy arkhitekturno-landshaftnoi orhanizatsii istorychnykh mist Ukrainy (na prykladi mista Uman). [Principles architecturally - landscape environment of historical cities of Ukraine (on the example of city of Uman)]. Abstract of candidate dissertation for Architectural Sciences (18.00.04 - Urban Planning and Landscape Architecture). Kyiv, 22 p. [In Ukrainian].

Yukhnovskyi, V. Yu., \& Zibtseva, O. V. (2018). Comparative analysis of settlements green plantations classification in Ukraine and post-Soviet countries. Proceedings of the Forestry Academy of Sciences of Ukraine, 16. https://doi.org/10.15421/411810. [In Ukrainian].

Zibtseva, O. V. (2014). The forming of planning structure and green spaces system in Vishhorod town. Scientific reports of the National University of Bioresources and Natural Resources of Ukraine, 7(49). [In Ukrainian].

О. В. Зибцева

Национальный университет биоресурсов и природопользования Украины, г. Киев, Украина

\title{
ОЗЕЛЕНЕНИЕ ЗАСТРОЕННЫХ ТЕРРИТОРИЙ МАЛЫХ ГОРОДОВ В КОНТЕКСТЕ СОБЛЮДЕНИЯ ГОСУДАРСТВЕННЫХ СТРОИТЕЛЬНЫХ НОРМ
}

\begin{abstract}
Устойчивое городское землепользования предполагает соблюдение действующих национальных стандартов. Отслежено соблюдение требований государственных строительных норм (ДБН 360-92. Планировка и застройка городских и сельских поселений) по планированию городов в части формирования системы зеленых насаждений на примере территории малого исторического города Вышгорода Киевской области и выявлены слабые места в самом нормативном документе по этому вопросу с целью дальнейшей оптимизации градостроительного планирования в Украине. Исследование выполнено в четкой последовательности в соответствии с рекомендациями, изложенными в ДБН и сравнением реальной ситуации на территории города, определенной путем натурных обследований. Методы исследования - экспертно-аналитические. Установлено, что на территории исследованного города ряд указанных нормативных рекомендаций нарушается или вообще игнорируется. Не соблюдаются минимальные расстояния посадок деревьев и кустов от зданий и сооружений, в уличных посадках мало кустовых растений. Уплотненное строительство, как правило, осуществляется за счет территорий зеленых насаждений, в том числе парка в центре города. Вообще не соблюдается рекомендация относительно максимального сохранения участков с существующими насаждениями. Нормативы по устройству площадок различного функционального назначения на придомовых территориях жилых массивов давно забыты, что, возможно, требует пересмотра самих нормативов, изложенных в ДБН.
\end{abstract}

Ключевые слова: зеленые насаждения; парк; планирование; устойчивое развитие.

O. V. Zibtseva

National University of Life and Environmental Sciences of Ukraine, Kyiv, Ukraine GREENING OF BUILT-UP AREAS OF TOWNS IN THE CONTEXT
OF COMPLIANCE WITH STATE CONSTRUCTION NORMS

Sustainable urban land use implies compliance of applicable national standards. Some experts consider that over the past twenty years, there have been grossly violated 109 state construction codes, of which 27 are fundamental for the industry. The review and improvement of the methodology of urban planning are relevant as well. The compliance of the requirements of state construction norms concerning the planning of cities in the part of the formation of the system of green spaces on the example of the territory of a small historical town of Vyshhorod of Kyiv Region has been analyzed. The weaknesses in the normative document were identified and measures for greening the built-up areas were recommended with the aim of further optimizing of urban planning in Ukraine in the context of sustainable eco-balanced development. The research is performed in strict accordance with the requirements set out in SBN-360-92 standard with a comparison of the actual situation in the city, determined by field surveys. The methods of research are expert-analytical. It is established that some normative recommendations are violated or even ignored at all in the territory of the city. Thus, the minimum distance of planting trees and shrubs from buildings and structures is not observed; street plantings have a limited assortment of shrub species and its quantity. Compacted construction, as a rule, is carried out at the expense of the territories of green plantations, including the central park of the city. The recommendations for maximum conservation of plots with existing plantations are not respected. The norms for the placement of different functional grounds in the residential areas have long been forgotten and require revision of the norms set forth in the SBN. The document does not clearly specify the nomenclature of structural elements of the territory of the complex green zone of the city. In most cases, the functional membership of structural elements is not defined, which is filed together: the green plantings of limited use and the green plantings of special purpose, repeated in different components of the so-called "other territories" of different functional purposes. We consider it expedient to introduce a direct valuation of the minimum provision of urban residents by green spaces of all categories.

Keywords: green plantings; park; planning; sustainable development. 